KS. ARKADIUSZ DOMASZK SDB

Wydział Prawa Kanonicznego

Uniwersytetu Kardynała Stefana Wyszyńskiego w Warszawie

\title{
KATOLICKI UNIWERSYTET AMERYKI (THE CATHOLIC UNIVERSITY OF AMERICA) W ŚWIETLE NORM PRAWA KANONICZNEGO
}

Treść: Wstęp. - 1. Uniwersytet katolicki w prawie kanonicznym. 1.1. Pojęcie i zadania uniwersytetu. - 1.2. Społeczność uniwersytecka. - 2. Katolicki Uniwersytet Ameryki (the Catholic University of America). - 2.1. Zarys historii. - 2.2. Aktualny kształt CUA. - 2.3. Katolicki wymiar CUA. - Zakończenie.

\section{Wstęp}

Uniwersytety pełnią znaczącą rolę w zakresie kształcenia studentów i badań naukowych. Również Kościół katolicki jest czynnie obecny w świecie nauki, m.in. prowadząc uniwersytety katolickie. Posiadają one swoją własną specyfikę, cele i założenia oraz programy. Tak, jak inne uniwersytety służą poszukiwaniu prawdy. Zadania konkretnego uniwersytetu wyłaniają się z jego historii, dokumentów założycielskich, posiadanego statutu, jak i całego etosu społeczności uniwersyteckiej.

Forma uniwersytetu katolickiego zależy ponadto od wskazań Kościoła, które jest ujęte w stosownych dokumentach Magisterium, jak również $\mathrm{w}$ prawie kanonicznym ${ }^{1}$. Studium poniższe

\footnotetext{
${ }^{1}$ Kościół katolicki oddziałuje w świecie wyższej edukacji poprzez dwie zasadnicze grupy uniwersytetów: katolickie i kościelne, por. zwłaszcza: JAN PAWEŁ II, Konstytucja apostolska o uniwersytetach katolickich Ex corde Ecclesiae (dalej Ex
} 
będzie poświęcone konkretnej uczelni, tj. Katolickiemu Uniwersytetowi Ameryki w Waszyngtonie (The Catholic University of America $=$ CUA). Przybliżenie tej uczelni pozwoli prześledzić, jak w tym przypadku wskazania Magisterium i normy kanoniczne znajdują swe praktyczne zastosowanie. Praca poniższa będzie z jednej strony przykładem akomodacji wskazań Kościoła w kraju, gdzie katolicy nie stanowią większości obywateli. Z drugiej strony, analiza tego uniwersytetu ma ukazać jego odrębność.

Przykład Uniwersytetu w Waszyngtonie, ściśle powiązanego z Kościołem katolickim, jest mniej znany w polskim środowisku. Przybliżając CUA, można postawić pytanie, czy rozwiązania amerykańskie mogą wnieść nowe bodźce do sytuacji polskich uczelni związanych z Kościołem?

W pierwszej części artykułu zostaną przeanalizowane normy prawa kanonicznego dotyczące uczelni katolickiej, w tym pojęcie i zadania uniwersytetu, a następnie zagadnienia dotyczące społeczności uniwersyteckiej. W drugiej części rozprawy zostanie zarysowana historia CUA, następnie aktualny kształt tego Uniwersytetu i katolicki wymiar uczelni.

\section{Uniwersytet katolicki w prawie kanonicznym}

\subsection{Pojęcie i zadania uniwersytetu}

Współczesne uniwersytety realizują wiele zadań. Myśl Kościoła katolickiego przypomina, że jednym z nadrzędnych ich praw

corde Ecclesiae), 15.08.1990, AAS 82 (1990), s. 1475-1508, tłum. pol. L'Osservatore Romano 10-11 (1990), s. 5-9; JAN PAwE七 II, Konstytucja apostolska Sapientia christiana o uniwersytetach i wydziałach kościelnych (dalej Sapientia christiana), 15.04.1979, AAS 71 (1979), s. 469-499. Istotnym dokumentem poprzedzającym wyżej wymienione była konstytucja papieska: PIUs XI, Constitutio apostolica Deus scientiarium Dominus, 24.05.1931, AAS 23 (1931), s. 241-262. Natomiast dokumentem przejściowym w okresie posoborowym były normy wydane przez Kongregację Wychowania Chrześcijańskiego, por. SACra Congregatio pro Institutione CatholiCa, Normae quaedam ad constitutionem apostolicam Deus scientiarium Dominus de studiis academicis ecclesiasticis recognoscendam, Typis Polyglottis Vaticanis 1968. 
i obowiązków jest poszukiwanie prawdy. Pisał o tym przed laty Karol Wojtyła $^{2}$. Jeszcze wyraźniej ujął tę samą myśl, już jako Jan Paweł II, w konstytucji Ex corde Ecclesiae: „uniwersytet katolicki ma zaszczytny obowiązek poświęcać się całkowicie działaniu na rzecz prawdy. Jest to właściwy mu sposób służenia jednocześnie godności człowieka i sprawie Kościoła (...), uniwersytet katolicki wyróżnia się wolnością poszukiwania całej prawdy o naturze, o człowieku i o Bogu. (...) $\mathrm{W}$ duchu swoistego uniwersalnego humanizmu, uniwersytet katolicki oddaje się całkowicie zgłębianiu wszystkich aspektów prawdy w ich istotowej więzi z Prawdą najwyższą, którą jest Bóg”3.

Tak wiara, jak i rozum, prowadzą do tej samej Prawdy Najwyższej. W kontekście uniwersyteckim, te przekonanie wyrazili również ojcowie Soboru Watykańskiego II, zwłaszcza w Deklaracji o wychowaniu chrześcijańskim. Dlatego Kościół otacza opieką uniwersytety, aby zadbać „o publiczną, stałą i powszechną obecność myśli chrześcijańskiej we wszelkich dążeniach do rozwoju wyższej kultury"

\footnotetext{
${ }^{2}$ Por. K. WojtyŁa, Uniwersytet katolicki: koncepcja i zadania (na 50-lecie KUL), Zeszyty Naukowe KUL 11 (1968) nr 3-4, s. 14. Spojrzenie na historię omawianej grupy uczelni, por. S. KunowsKi, Rola uniwersytetów katolickich whistorii nauki i oświaty, tamże, s. 33-50; Uniwersytety, w: Podręczna encyklopedya kościelna, t. 3940, Warszawa-Lublin-Łódź 1914, s. 398-403; I. Cecchetti, P. PAschini, Università, w: Enciclopedia cattolica, t. 12, Città del Vaticano 1954, s. 858-863; S. Wielgus, Uniwersytety katolickie $i$ kościelne instytuty wyższego nauczania, Lublin 1996; P. GACH, Z. SKWIERCZYŃsKi, Uniwersytety katolickie, w: Encyklopedia katolicka, t. 19, red. E. Gigilewicz, Lublin 2013, kol. 1367-1369.

${ }^{3}$ Ex corde Ecclesiae, nr 4. Por. Szkoła i uniwersytet w życiu Kościoła i narodu, w: II Polski Synod Plenarny (1991-1999), Poznań 2001, nr 15-16. Jedną ze współczesnych dyskusji na temat: czym jest uniwersytet katolicki, jakie są jego zadania, itp., por. A. MacIntyre, Katolickie uniwersytety. Niebezpieczeństwa, nadzieje, wybory, Znak 11 (2005), s. 18-42; P. GuTowsKi, Katolickie uniwersytety a ideał pelnej prawdy, tamże, s. 43-57; P. KоsтүŁo, W poszukiwaniu idei uniwersytetu katolickiego, tamże, s. 58-78; P. MAzUrKIEWICZ, Uniwersytet z „przymiotnikiem”, tamże, s. 85-93.

${ }^{4}$ Soвór WАтүкаŃsкi II, Deklaracja o wychowaniu chrześcijańskim Gravissimum educationis, 28.10.1965, w: Sobór Watykański II, Konstytucje, Dekrety, Deklaracje, tekst polski, Poznań 2002, s. 314-324, nr 10. Por. W. Granat, Uniwersytet katolicki w świetle uchwał Soboru Watykańskiego II, Zeszyty Naukowe KUL 11 (1968) nr 3-4, s. 17-31.
} 
Każdy uniwersytet tworzą konkretni ludzie. Wspólnota osób (universitas): wykładowców i studentów, dążących do prawdy, buduje element podmiotowy uczelni ${ }^{5}$. Natomiast od strony przedmiotowej „wyraz universitas wskazuje na powszechność samej prawdy, na wielość dziedzin poznania, które jednak trwają we wzajemnym odniesieniu i wzajemnie się warunkują. Uniwersytet pragnie ogarnąć całą prawdę, prawdę jako jedność, ale droga do tego jest wieloraka"6.

Podobnie treść konstytucji Ex corde Ecclesiae określi uniwersytet katolicki, w ujęciu podmiotowym i przedmiotowym. „Każdy uniwersytet katolicki, ze względu na swój charakter uniwersytecki, jest wspólnotą akademicką, która działając w sposób ściśle naukowy i krytyczny przyczynia się do ochrony i postępu ludzkiej godności oraz dziedzictwa kulturowego poprzez prace badawcze, nauczanie i różnorakie usługi świadczone na rzecz wspólnot lokalnych, krajowych i międzynarodowych"7.

Gwarantem wypełnienia tak określonej tożsamości i misji jest autonomia uniwersytetu dająca przestrzeń wolności akademickiej, w badaniach naukowych i nauczaniu ${ }^{8}$. Wolność w poszukiwaniach i nauczaniu respektuje zasady i metody każdej dyscypliny, zachowuje prawa jednostek i społeczności, a także posiada granice, zakreślone przez wymogi prawdy i dobra wspólnego ${ }^{9}$. Kościół broni reguły

${ }^{5}$ „Uniwersytet katolicki, jak każdy uniwersytet, jest społecznością uczonych reprezentujących różne dziedziny ludzkiej wiedzy (...)”, Ex corde Ecclesiae, art. 2 $\$ 1$.

${ }^{6} \mathrm{~K}$. WojtyŁa, Uniwersytet katolicki, s. 14.

${ }^{7}$ Ex corde Ecclesiae, nr 12. Prof. F. LEMPA sformułowanie z nr 12 komentuje następująco: „uniwersytetowi katolickiemu w niczym nie można odmówić charakteru prawdziwego uniwersytetu", tenże, Doktrynalno-prawne przesłanie konstytucji apostolskiej Jana Pawła II o uniwersytetach katolickich Ex corde Ecclesiae, Roczniki Nauk Prawnych 4 (1994), s. 109.

${ }^{8}$ Por. Ex corde Ecclesiae, nr 12; G. Rodriguez-Izquierdo, La constitution apostolica 'Ex Corde Ecclesiae' sobre las Universidades catolicas, w: La mision docente de la Iglesia. XI Jornadas de la Asociacion Espanola de Canonistas Madrid 3-5 abril 1991, red. J. M. Urteaga, Salamanca 1992, s. 209-214.

${ }^{9}$ Por. Ex corde Ecclesiae, art. $2 \$ 5$. 
wolności badań akademickich, ale też przypomina, „że zasady tej nie wolno oddzielać od odpowiedzialności etycznej uczonego"10.

Papieska konstytucja szczególnie wydobywa cztery cechy, które wyróżniają katolicki charakter uniwersytetu: chrześcijańska inspiracja, podejmowana $\mathrm{w}$ świetle wiary katolickiej refleksja nad stanem ludzkiej wiedzy, wierność wobec chrześcijańskiego orędzia oraz instytucjonalne zaangażowanie w służbę ludowi Bożemu i rodzinie ludzkiej ${ }^{11}$. Myśl katolicka jest bardzo mocno obecna w życiu całego uniwersytetu. Tym samym, badania naukowe w obrębie każdej dyscypliny, jak i międzydyscyplinarne, wyróżniają się: dążeniem do integracji wiedzy; dialogiem pomiędzy wiarą i rozumem; troską o etyczny wymiar nauki i perspektywą teologiczną ${ }^{12}$.

Ogólne zarysowanie natury uniwersytetów katolickich, zostało ujęte w normach prawnych, które zawiera druga część konstytucji $E x$ corde Ecclesiae ${ }^{13}$. Katolicki charakter uczelni, wyrażający się w badaniach i nauczaniu, podkreślają również akty formalne. Uniwersytet „jest związany z Kościołem już to formalną więzią konstytucyjną i statutową, już to na mocy decyzji podjętej przez osoby odpowiedzialne w imieniu całej instytucji” ${ }^{\prime 4}$. Odpowiedni dokument (y) potwierdza

\footnotetext{
${ }^{10}$ Szkoła i uniwersytet w życiu Kościoła i narodu, w: II Polski Synod Plenarny, nr 17. O wolności badań, która nie sprzeciwia się otwartości na prawdę, tak że istnieje wzajemny związek, a nie sprzeczność badań i prawdy, por. Jan PaweŁ II, Homilia Jana Pawła II podczas obchodów Jubileuszu Nauczycieli Akademickich 'Chrystus nie zagraża wolności badań’, 10.09.2000, Wiadomości KAI 14.09.2000, s. 23-24; tenże, Przemówienie Jana Pawła II do uczestników Światowego Spotkania Nauczycieli Akademickich 'Laboratoria kultury', 09.09.2000, Wiadomości KAI 14.09.2000, s. 24-25.

${ }^{11}$ Por. Ex corde Ecclesiae, nr 13.

${ }^{12}$ Por. tamże, nr 15-20.

${ }^{13}$ Tekst prawny należy interpretować w jego kontekście. W tym znaczeniu, pierwsza część konstytucji apostolskiej Ex corde Ecclesiae, stanowi kontekst, w którym ustawodawca kościelny podaje kryteria do interpretacji drugiej, tj. normatywnej części wymienionej konstytucji, por. J. H. Provost, A canonical commentary on «Ex corde Ecclesiae», w: Catholic Universities in Church and Society. A Dialogue on Ex Corde Ecclesiae, red. J. P. Langan, Washington D.C. 1993, s. 106.

${ }^{14}$ Ex corde Ecclesiae, art. $2 \$ 2$. Termin „katolicki” posiada wiele wymiarów. Oprócz oficjalnego potwierdzenia w formie dokumentu czy statutu, chodzi również
} 
„katolickość” uczelni. „Każdy uniwersytet katolicki winien dać wyraz swej katolickiej tożsamości poprzez deklarację określającą charakter jego misji lub inny stosowny dokument publiczny (...). Powinien także zapewnić sobie - przede wszystkim przez przyjęcie odpowiedniej struktury i regulaminów - środki gwarantujące zachowanie i pozwalające na wyrażanie tej tożsamości" ${ }^{15}$. Deklarację dotyczącą charakteru uniwersytetu zwykle zawiera statut.

Charakter uniwersytetu potwierdza następnie zgoda władzy kościelnej. Formalny akt pozwala używać słowa „katolicki”, w nazwie uczelni. Norma Kodeksu z 1983 r. stanowi: „żaden uniwersytet, chociaż rzeczywiście katolicki, nie może używać nazwy uniwersytet katolicki, bez zgody kompetentnej władzy kościelnej" ${ }^{16}$. Zastrzeżenie nazwy dotyczy nowo utworzonej uczelni, jak i przekształconej, wcześniej już istniejącej. Prawodawca kościelny stwierdza, że Kościół ma prawo do erygowania takich uniwersytetów ${ }^{17}$. Autoryzacja dokonana przez władzę kościelną potwierdza na sposób kanoniczny, że konkretny uniwersytet uczestniczy w misji nauczycielskiej Kościoła ${ }^{18}$. Tożsamość uczelni wyraża także norma zobowiązująca rektora uniwersytetu katolickiego do złożenia wyznania wiary, przed wielkim

o przekaz wartości w środowisku uczelni, por. J. H. Provost, The Canonical Aspects of Catholic Identity in the Light of Ex corde Ecclesiae, Studia Canonica 25 (1991) 1, s. 155-191.

${ }^{15}$ Ex corde Ecclesiae, art. $2 \S 3$. Katolickie nauczanie winno uszanować wolność sumienia, por. tamże, art. $2 \$ 4$.

${ }^{16}$ Codex Iuris Canonici, auctoritatae Joannis Pauli pp. II promulgatus, AAS 75 (1983-II) XXX+1-318, Kodeks Prawa Kanonicznego, przekład polski zatwierdzony przez Konferencję Episkopatu (dalej KPK 1983), Poznań 1984, kan. 808.

17 „Kościół ma prawo zakładania uniwersytetów i kierowania nimi. Przyczyniają się one do pogłębienia kultury ludzi i pełniejszego rozwoju osoby ludzkiej, a także do wypełnienia posługi nauczania w Kościele”, tamże, kan. 807.

${ }^{18}$ Por. J. Horta Espinoza, „Eccomi, manda me!”. Introduzione al libro III del Codice di Diritto Canonico, Roma 2011, s. 127. Katolickiej tożsamości uniwersytetu nie można jednak sprowadzić tylko do wybranych aktów formalnych, warunkowanych prawem kanonicznym. Dyskusję nad tożsamością katolickich uczelni w USA, por. M. J. Buckley, The Catholic University and the Promise Inherent in its Identity, w: Catholic universities in Church and society, s. 74-89. 
kanclerzem ${ }^{19}$. Gdyby jednak uniwersytet odszedł od swej tożsamości, od pełnej łączności z Kościołem, to kompetentna władza kościelna, może taką uczelnię pozbawić nazwy „katolickiej”20.

Sytuację prawną uczelni wyższych w Polsce, które są związane z Kościołem katolickim, reguluje Konkordat zawarty ze Stolicą Apostolską. Umowa konkordatowa gwarantuje Kościołowi katolickiemu prawo zakładania i prowadzenia szkół wyższych oraz seminariów duchownych ${ }^{21}$. Status szkół wyższych, tryb i zakres uznawania kościelnych stopni i tytułów, status prawny wydziałów teologii katolickiej na uniwersytetach państwowych regulują umowy między Rządem Rzeczypospolitej Polskiej a Konferencją Episkopatu Polski, upoważnioną przez Stolicę Apostolską ${ }^{22}$. Prawo do zakładania własnych uniwersytetów przez Kościół katolicki, w praktyce należy odnosić do

\footnotetext{
${ }^{19}$ Por. KPK 1983, kan. 833 n.7.

${ }^{20}$ Por. W. Gór ALSKi, Uniwersytet katolicki w świetle prawa kanonicznego, w: Nowy uniwersytet dla Warszawy, Materiały z sympozjum w Akademii Teologii Katolickiej z dn. 09.11.1998, Warszawa 1999, s. 45.

${ }^{21}$ Por. Konkordat między Stolica Apostolska a Rzeczpospolita Polska podpisany w Warszawie dnia 28 lipca 1993 r., Dz. U. z 1998, nr 51, poz. 318, art. 15, ust. 1.

${ }^{22}$ Por. tamże, art. 15, ust. 2; Umowa między rządem Rzeczypospolitej Polskiej a Konferencją Episkopatu Polski w sprawie statusu prawnego szkół wyższych zakładanych i prowadzonych przez Kościót Katolicki, w tym uniwersytetów, odrębnych wydziałów $i$ wyższych seminariów duchownych, oraz w sprawie trybu i zakresu uznawania przez Państwo stopni i tytułów nadawanych przez te szkoły wyższe $z$ dnia 1 lipca 1999, Dz. U. z 1999, nr 63, poz. 727. Niektóre wydziały teologiczne istnieją również w ramach polskich uczelni państwowych. Problematykę uczelni związanych z Kościołem w Polsce, por. Szkoła i uniwersytet $w \dot{z} y c i u$ Kościoła i narodu, w: II Polski Synod Plenarny, nr 40-44, 66-76; A. DĘBIŃsKı, Zadania katolickiego uniwersytetu w świetle uchwał II Polskiego Synodu Plenarnego, w: Dzieło II Synodu Plenarnego w Polsce, red. S. Tymosz, Lublin 2001, s. 95-105; E. GóRecki, Sytuacja prawna katolickich szkół wyższych w Polsce, w: Zadanie nauczycielskie Kościoła wobec wyzwań XXI wieku, Radom 2010, s. 145-152; A. Domaszk, Odrębność wydziałów kościelnych Uniwersytetu Kardynała Stefana Wyszyńskiego w Warszawie $w$ świetle prawa kanonicznego, Prawo Kanoniczne 52 (2009) nr 1-2, s. 85-113.
} 
prawa poszczególnych państw w tym zakresie; uniwersytety katolickie muszą respektować również ustawy państwowe ${ }^{23}$.

Decyzję o założeniu uniwersytetu katolickiego mogą podjąć różnorodne podmioty: Stolica Święta, Konferencja Episkopatu lub inne zgromadzenie hierarchii katolickiej, czy również biskup diecezjalny ${ }^{24}$. Ten ostatni może wydać zgodę na założenie uniwersytetu katolickiego przez instytut zakonny lub inną publiczną osobę prawną ${ }^{25}$. Nadto inne osoby duchowne lub świeckie mogą założyć tego typu uniwersytet, za zezwoleniem kompetentnej władzy kościelnej ${ }^{26}$. Tak utworzony uniwersytet posiada publiczną kościelną osobowość prawną ${ }^{27}$.

Odpowiedzialność za uczelnie wyższe, zależne od Kościoła, spoczywa na Stolicy Apostolskiej. Organem koordynującym sprawy uczelni katolickich jest Kongregacja Wychowania Katolickiego ${ }^{28}$. Troska o uniwersytety spoczywa również na Konferencji Episkopatu, która powinna zadbać o to, ,ażeby na podległym im terytorium działały właściwie rozmieszczone uniwersytety lub przynajmniej wydziały, w których byłyby kultywowane i wykładane z zachowaniem ich naukowej autonomii różne dyscypliny, przy uwzględnieniu doktryny katolickiej”29. Własną odpowiedzialność ponosi biskup

\footnotetext{
${ }^{23}$ Por. Ustawa z 27 lipca 2005 r. Prawo o szkolnictwie wyższym, Dz. U. z 2005 r. Nr 164, poz. 1365 z późn. zm.

${ }^{24}$ Por. Ex corde Ecclesiae, art. $3 \$ 1$; F. LEMPA, Doktrynalno-prawne przesłanie, s. 114.

${ }^{25}$ Por. Ex corde Ecclesiae, art. $3 \$ 2$.

${ }^{26}$ Por. tamże, art. $3 \$ 3$; J. HeRvadA, Vetera et nova. Questiones de derecho canonico $y$ afines (1958-1991), t. 2, Pamplona 1991, s. 969-973.

${ }^{27}$ Por. KPK 1983, kan. 116.

${ }^{28}$ Por. Joannes Paulus II, Constitutio apostolica de Romana Curia Pastor Bonus, 28.06.1988, AAS 80 (1988), s. 841-912, art. 116, \$1. 3-4. Po publikacji konstytucji na temat uczelni katolickich, został wydany dokument kierunkujący prace Konferencji Episkopatów, nad dostosowaniem prawa partykularnego do papieskiej konstytucji, por. Cogregation for Catholic Education, Directives to Assist in the Formulation of the Apostolic Constitution Ex Corde Ecclesiae, 21.01.1991, w: Ex Corde Ecclesiae. Documents Concerning Reception and Implementation (dalej: Ex Corde Ecclesiae. Documents), red. A. Gallin, Notre Dame 2006, s. 66-68.

${ }^{29}$ KPK 1983, kan. 809.
} 
diecezjalny, który ma przyczyniać się do właściwego funkcjonowania uniwersytetów katolickich na terenie jego diecezji, ma też prawo i obowiązek czuwać nad zachowaniem ich charakteru katolickiego, inicjować działania chroniące katolicką tożsamość uczelni ${ }^{30}$. Biskup, w razie zaistnienia problemów, podejmuje odpowiednie kroki w porozumieniu z władzami uczelni. Właściwym miejscem na określenie możliwych działań dla biskupa są wcześniej zatwierdzone statuty uczelni ${ }^{31}$.

Zadania uniwersytetu katolickiego dotyczą następnie ewangelizacji w świecie kultury i wiedzy, podejmowane przez całą instytucję naukową. „Wszystkie podstawowe formy działalności uniwersytetu są związane i zharmonizowane z misją ewangelizacyjną Kościoła (...); formacja dokonująca się w kontekście wiary winna kształtować ludzi zdolnych do rozumnego i krytycznego osądu oraz świadomych transcendentnej godności ludzkiej osoby; formacja zawodowa powinna wpajać także wartości moralne oraz postawę służby ludziom i społeczności; dialog z kulturą ma sprzyjać lepszemu rozumieniu wiary; poszukiwania teologiczne mają umożliwiać wierze wypowiadanie się we współczesnym języku"32. Uniwersytet katolicki jest wewnętrznie złączony ze zbawczą misją Kościoła, który jest żywą społecznością wiernych, a nie tylko hierarchią ${ }^{33}$. Ponadto można też stwierdzić, że misja kulturotwórczą jest esencją każdego uniwersytetu, który jest areopagiem kultury ${ }^{34}$.

\footnotetext{
${ }^{30}$ Por. Ex corde Ecclesiae, art. $5 \$ 2$.

${ }^{31}$ Por. W. Gór Alski, Uniwersytet katolicki, s. 49.

${ }^{32}$ Ex corde Ecclesiae, nr 49. Por. J. Dyduch, Posłannictwo uniwersytetów w świetle dokumentów kościelnych, Prawo Kanoniczne 38 (1995) nr 1-2, s. 83-87.

${ }^{33}$ Por. J. Komonchaк, The Catholic university in the Church, w: Catholic universities in Church and society, s. 35-51.

${ }^{34}$ Por. J. Dyduch, Posłannictwo uniwersytetów, s. 79-83. Uniwersytet jest instytucją odpowiedzialną za staranną edukację narodu, tak by całe społeczeństwo było „światłe”, por. A. Pelczar, Wyzwania i zagrożenia dla misji uniwersytetu, w: Nowy uniwersytet dla Warszawy. Materiały z sympozjum w Akademii Teologii Katolickiej z dn. 09.11.1998, Warszawa 1999, s. 31.
} 
Jednym z wyrazów misji ewangelizacyjnej jest duszpasterstwo akademickie. Prawodawca zwraca uwagę na potrzebę jego zorganizowania i zobowiązuje biskupa diecezjalnego do zbudowania właściwych struktur duszpasterstwa, także na uczelniach niekatolickich. „Biskup diecezjalny powinien otoczyć studentów szczególną troską duszpasterską, nawet erygując dla nich parafię albo przynajmniej wyznaczając do tego na sposób stały niektórych kapłanów. Winien również zatroszczyć się o to, żeby na uniwersytetach, także niekatolickich, powstały katolickie ośrodki uniwersyteckie, świadczące młodzieży pomoc, zwłaszcza duchową" ${ }^{35}$. Duszpasterstwa studenckie często są skupione wokół kościołów rektoralnych ${ }^{36}$, ale może być ustanowiona parafia personalna dla studentów ${ }^{37}$.

Jan Paweł II przypomina w konsty tucji Ex corde Ecclesiae, że uniwersytet katolicki winien zatroszczyć się o rozwój duchowy tych, którzy wyznają wiarę katolicką. Użyte środki mają ułatwić integrację formacji ludzkiej i zawodowej z wartościami religijnymi, rozwój intelektualny łączyć z religijnym wymiarem życia ${ }^{38}$. Jednym z tych środków jest zaangażowanie stosownej liczby duszpasterzy, ale także osób konsekrowanych i świeckich liderów ${ }^{39}$. Zachęta do uczestnictwa w pracy duszpasterstwa akademickiego i do udziału w jego inicjatywach jest kierowana, nie tylko do studentów, ale do wszystkich członków społeczności uniwersyteckiej. Celem tego duszpasterstwa jest przygotowanie do aktywnego udziału w życiu Kościoła, rozwój szacunku dla życia rodzinnego, odkrywanie posiadanego

\footnotetext{
${ }^{35}$ KPK 1983, kan. 813. Por. J. Dyduch, Posłannictwo uniwersytetów, s. 87-90.

${ }^{36}$ Często troska biskupa wyraża się w ustanowieniu kapelanów, zaangażowanych w duszpasterstwo akademickie. Kanoniczne funkcje kapelana, por. KPK 1983, kan. 564-566.

${ }^{37}$ Por. tamże, kan. 518. Akademicką parafią personalną w Polsce jest np. utworzona w 2004 r. parafia pod wezwaniem św. Ireneusza w Częstochowie, por. http://www. parafia.emaus.czest.pl/ (data dostępu: 16.10.2014).

${ }^{38}$ Por. Ex corde Ecclesiae, art. $6 \$ 1$.

${ }^{39}$ Por. tamże, art. $6 \S 2$; Gravissimum educationis, nr 10.
} 
powołania ${ }^{40}$. W realizacji zadań duszpasterskich istotną rolę pełnią różne akademickie stowarzyszenia lub wspólnoty życia apostolskiego i duchowego ${ }^{41}$.

Katolicki uniwersytet winien zachowywać jedność z Kościołem powszechnym, Stolicą Apostolską i z Kościołem partykularnym. Jednym z narzędzi, temu służącemu są sprawozdania. Uniwersytet katolicki winien składać kompetentnej władzy kościelnej okresowe sprawozdanie dotyczące jego działalności ${ }^{42}$. Narzędziem przydatnym w rozwoju naukowym, ale i w zachowaniu własnej tożsamości, jest współpraca między wszystkimi uniwersytetami katolickimi i kościelnymi oraz innymi uczelniami ${ }^{43}$. Przykładem współpracy jest Międzynarodowa Federacja Uniwersytetów Katolickich, którą powołał Pius XII w 1949 r. ${ }^{44}$ Wskazany jest także współudział uniwersytetów $\mathrm{w}$ programach rządowych oraz $\mathrm{w}$ działalności różnych organizacji krajowych i międzynarodowych ${ }^{45}$. Przykładem współpracy pomiędzy uczelniami w Unii Europejskiej jest program Socrates-Erazmus. Uczelnie katolickie, jeśli spełniają określone warunki formalne, mogą także brać udział w tym programie.

\subsection{Społeczność uniwersytecka}

$\mathrm{Na}$ kształt uniwersytetu znacząco wpływają wykładowcy oraz zakres i sposób wykładania przez nich nauki. Wymagania dla nauczycieli akademickich uniwersytetów katolickich wylicza treść normy z Kodeksu z 1983 r. „Władza kompetentna, zgodnie z postanowieniami statutów, ma obowiązek zatroszczyć się o to, ażeby nauczycielami uniwersytetów katolickich mianować osoby, które obok odpowiednich kwalifikacji naukowych i pedagogicznych, odznaczają

\footnotetext{
${ }^{40}$ Por. Ex corde Ecclesiae, nr 41; Szkoła i uniwersytet w życiu Kościoła i narodu, w: II Polski Synod Plenarny, nr 68.

${ }^{41}$ Por. Ex corde Ecclesiae, nr 42.

${ }^{42}$ Por. tamże, art. $5 \$ 3$.

${ }^{43}$ Por. tamże, art. $7 \$ 1$.

${ }^{44}$ Por. PIUs XII, Catholicas studiorum universitates, 27.03.1949, AAS 42 (1950), s. 385-387.

${ }^{45}$ Por. Ex corde Ecclesiae, art. $7 \$ 2$.
} 
się również nieskazitelnością doktryny i dobrymi obyczajami. Gdy zaś braknie tych wymogów, powinni być usunięci ze stanowiska, z zachowaniem sposobu określonego w statutach" ${ }^{46}$. Szczegółowe normy na ten temat zawierają statuty uczelni. Wykładowcy przedmiotów teologicznych muszą ponadto otrzymać odrębne zlecenie (mandatum) od władzy kościelnej. „We wszystkich wyższych instytutach nauczyciele przedmiotów teologicznych muszą mieć zlecenie kompetentnej władzy kościelnej" ${ }^{37}$. Wykład teologii rodzi szereg pytań o relację posługi teologów do Magisterium Kościoła, dlatego Kongregacja Nauki Wiary opublikowała osobną instrukcję na ten temat ${ }^{48}$.

Wspomniany wyżej mandat zrodził szeroką dyskusję, czym on jest? W odniesieniu do uczelni i wydziałów kościelnych, wykładowcy nauk dotyczących wiary i obyczajów otrzymują, według konstytucji Sapientia Christiana, misje kanoniczna od wielkiego kanclerza lub osoby przez niego delegowanej ${ }^{49}$. Wykładowcy ci mają też obowiązek złożenia wyznania wiary przed rektorem, który jest kapłanem, lub przed ordynariuszem miejsca albo przed ich delegatami ${ }^{50}$. Od wykładowców uniwersytetów katolickich konstytucja Ex corde Ecclesiae domaga się mandatu, który powinien być udzielony w formie pisemnej ${ }^{51}$. Dokument ten, natury administracyjnej, jest także publicznym poświadczeniem kwalifikacji i udzielenia określonych

\footnotetext{
${ }^{46}$ KPK 1983, kan. $810 \$ 1$.

${ }^{47}$ Tamże, kan. 812. Por. T. GaŁKowski, Zlecenie (mandatum) do nauczania przedmiotów teologicznych (kann. 812 i 818 KPK), Seminare 26 (2009), s. 97-113.

${ }^{48}$ Por. Congregatio De Doctrina Fidei, Instructio de ecclesiali theologi vocatione Donum veritatis, 24.05.1990, AAS 82 (1990), s. 1550-1570, tekst polski w: W trosce o petnię wiary. Dokumenty Kongregacji Nauki Wiary 1966-1994, Tarnów 1995, s. 353-369.

${ }^{49}$ Por. Sapientia Christiana, art. 27.

${ }^{50}$ Por. KPK 1983, kan. 833, nr 7.

${ }^{51}$ Por. A. Montan, L'Educazione cattolica (cann. 793-821), w: Gruppo italiano docenti di diritto canonico, La funzione di insegnare della Chiesa, XIX Incontro di studio passo della Mendola - Trento, 29.06-03.07.1992, Milano 2001, s. 90. Obowiązek uzyskania mandatu jest przede wszystkim personalny: profesor winien o to zadbać, por. J. M. Huels, The Juridic Status of Catholic Faculties of Theology: Overview of the Universal Law, Studia Canonica 37 (2003), s. 316-317.
} 
obowiązków nauczycielskich wykładowcy przez władzę kościelną. Zarazem mandat potwierdza, że jest on w komunii z Kościołem katolickim; z drugiej strony, mandat nie identyfikuje profesora $\mathrm{z}$ pełnym autorytetem kościelnym ${ }^{52}$. Wykładowca otrzymując mandat, składa wyznanie wiary i przysięgę wierności: „od tej chwili teolog jest oficjalnie powołany do przedstawiania i wyjaśniania z całą dokładnością integralnej nauki wiary" ${ }^{53}$. Odejście od koncepcji misji kanonicznej na rzecz mandatu pozwala ponadto na uniknięcie nadmiernego tonu konfesyjności uniwersytetu katolickiego oraz większe podkreślenie jego autonomii ${ }^{54}$. W toczonej dyskusji można spotkać się ze stwierdzeniem, że misja kanoniczna jest mocniejszym wyrażeniem niż mandat, ale oba terminy prowadzą do zbliżonych konsekwencji ${ }^{55}$. Jednakże analiza aktualnych norm rodzi wątpliwości, czy nie należy rozważać tylko zagadnienia mandatu, a traktować misji kanonicznej, jako prawa, które utraciło moc obowiązującą ${ }^{56}$. Użycie słowa mandat w omawianej kwestii pozwala ponadto uniknąć nieporozumień, gdy termin misja oznacza przekazanie władzy jurysdykcyjnej, a takiej nie przekazuje się wykładowcom uniwersyteckim ${ }^{57}$.

\footnotetext{
52 Por. A. Montan, L’Educazione cattolica, s. 90; J. Horta Espinoza, „Eccomi, manda me!", s. 130-131; S. A. EuART, Catholic education, w: New commentary on the Code of Canon Law, red. J. P. Beal, J. A. Coriden, T. J. Green, Mahwah 2000, s. 966969; tenże, Comment, w: Catholic universities in Church and society, s. 137-145.

${ }^{53}$ Donum veritatis, nr 22.

${ }^{54}$ Por. J. Horta Espinoza, „Eccomi, manda me!”, s. 131.

${ }^{55}$ Por. F. R. McManus, Commentary cc. 815-821, w: New commentary on the Code of Canon Law, red. J. P. Beal, J. A. Coriden, T. J. Green, Mahwah 2000, s. 975. Mandatu udziela Stolica Apostolska, biskup diecezjalny lub Konferencja Episkopatu, por. S. A. EuART, Catholic education, s. 970. Z uprawnienia do przekazania mandatu nie są wykluczeni ordynariusze zakonni; również mogą być dopuszczalne uprawnienia do delegowania takich decyzji, por. J. H. Provost, A canonical commentary on «Ex corde Ecclesiae», s. 123-124.

${ }^{56}$ Por. T. GaŁkowski, Zlecenie (mandatum) do nauczania przedmiotów teologicznych, s. 104-108. Tenże ukazuje trudności zastosowania „mandatu” na gruncie uniwersytetów i uczelni katolickich w Ameryce Północnej, por. tamże, s. 99-102.

${ }^{57}$ Por. J. H. Provost, A canonical commentary on «Ex corde Ecclesiae», s. 121-123.
} 
Omawianą problematykę podjął również II Polski Synod Plenarny. „Wykładowcy przedmiotów należących do dziedziny wiary lub obyczajów powinni być świadomi tego, że zadanie to wymaga zachowania ścisłej łączności $z$ autentycznym nauczaniem Kościoła, przede wszystkim zaś z magisterium Biskupa Rzymskiego. Po złożeniu przepisanego wyznania wiary otrzymują oni misję kanoniczną od wielkiego kanclerza lub jego delegata. W momencie mianowania wszyscy pracownicy naukowi i administracyjni winni zostać poinformowani o katolickiej tożsamości uniwersytetu lub wydziału, o tym, co z niej wynika, jak również o ciążącym na nich obowiązku jej umacniania, a przynajmniej respektowania" ${ }^{58}$. Wypada dodać, że przytoczony dokument akcentuje misję kanoniczną, nie wspominając o mandacie. Z drugiej strony, rozróżnienie na uczelnie katolickie i kościelne w tymże dokumencie nie jest precyzyjne. Na przykład wyliczając uczelnie, jako katolickie, które faktycznie są lub były kościelnymi ${ }^{59}$.

Treść konstytucji Ex corde Ecclesiae zwraca następnie uwagę na to, że poszukiwania naukowe i wykład dyscyplin naukowych uwzględniać powinny katolicką doktrynę. Jest to także odpowiedzialność Konferencji Episkopatu lub zainteresowanego biskupa diecezjalnego: „Konferencje Episkopatu oraz zainteresowani biskupi diecezjalni mają obowiązek i prawo czuwać nad tym, by na katolickich uniwersytetach wiernie były przestrzegane zasady doktryny katolickiej"60. Biskup diecezjalny nie powinien jednak interweniować bezpośrednio, $\mathrm{w}$ razie zaistnienia problemów. Raczej winien współpracować z władzami

\footnotetext{
${ }^{58}$ Szkoła i uniwersytet $w$ życiu Kościoła i narodu, w: II Polski Synod Plenarny, nr 20. Dokument synodalny rozciąga odpowiedzialność za tożsamość uczelni na wszystkich jej pracowników. O obecności świeckich wykładowców na uczelniach katolickich i kościelnych, por. E. Zanettr I laici nel munus docendi della Chiesa, w: Gruppo Italiano Docenti di Diritto Canonico, I laici nella ministerialità della Chiesa. XXVI Incontro di Studio Centro Dolomiti „Pio X” - Borca di Cadore 28 giugno - 3 luglio 1999, Milano 2000, s. 213.

${ }^{59}$ Por. Szkoła i uniwersytet w życiu Kościoła i narodu, w: II Polski Synod Plenarny, nr 43-44.

${ }^{60}$ KPK 1983, kan. $810 \S 2$.
} 
uczelni; wzajemny szacunek, komunikacja i kooperacja obu stron pozwolą rozwiązać trudności i zachować myśl katolicką ${ }^{61}$.

O związku z Kościołem świadczą także poszukiwania teologiczne i wykład tego przedmiotu: „kompetentna władza kościelna powinna zatroszczyć się o to, by na katolickich uniwersytetach został utworzony wydział teologiczny albo instytut lub przynajmniej katedra teologii, prowadząca wykłady także dla studentów świeckich"62. Dialog nauki i wiary obejmuje wykłady z różnych dyscyplin: „na każdym uniwersytecie katolickim winny być prowadzone wykłady, uwzględniające głównie te kwestie teologiczne, które mają związek z przedmiotami wykładanymi na jego wydziałach" ${ }^{63}$.

Wydziały teologiczne, oprócz funkcji badawczych, mogą znacząco pełnić funkcję duchowej integracji osób tworzących uniwersytet oraz rozmaitych dziedzin badawczych ${ }^{64}$. Uczelnia katolicka buduje także przestrzeń dialogu światopoglądowego, ekumenicznego i międzyreligijnego ${ }^{65}$.

Katolicka tożsamość uniwersytetu zależy, tak od władz uczelni, jak i od wszystkich jego pracowników, naukowych i administracyjnych ${ }^{66}$. Własnym obowiązkiem władz uczelnianych jest troska o posiadany charakter uniwersytetu. Przyjęcie nowych pracowników, czy moment mianowania, jest stosowny do zdeklarowania charakteru uczelni: „W momencie mianowania wszyscy pracownicy naukowi i administracyjni winni zostać poinformowani o katolickiej tożsamości

\footnotetext{
${ }^{61}$ Por. S. A. Euart, Catholic education, s. 965.

${ }^{62}$ KPK 1983, kan. 811 §1. Por. Gravissimum educationis, nr 10. W kontekście europejskim, nauczanie teologii rodzi nowe wyzwania, por. Studium teologii w ramach logiki „Procesu Bolońskiego”. List Kongregacji Edukacji Katolickiej dotyczacy spraw związanych z uczelniami katolickimi, 30.03.2009, Akta Konferencji Episkopatu Polski 16 (2009), s. 25-30.

${ }^{63}$ KPK 1983, kan. $811 \S 2$.

${ }^{64}$ Por. Szkoła i uniwersytet w życiu Kościoła i narodu, w: II Polski Synod Plenarny, nr 67.

${ }^{65}$ Por. tamże, nr 71.

${ }^{66}$ Por. Ex corde Ecclesiae, art. $4 \$ 1$.
} 
instytutu oraz o jej implikacjach, jak również o własnym obowiązku umacniania, a przynajmniej respektowania tej tożsamości" ${ }^{67}$.

W dalszej pracy nauczycieli akademickich, w ich badaniach naukowych i nauczaniu oczekuje się od nich określonych postaw. Chodzi m.in. o respektowanie katolickiej doktryny i moralności, dochowanie wierności Magisterium Kościoła, który autentycznie interpretuje Pismo Święte i Tradycję ${ }^{68}$.

Społeczność uniwersytecką mogą stanowić chrześcijanie innych wyznań, niechrześcijanie lub osoby niewierzące, tak spośród pracowników, jak i studentów. Konstytucja Ex corde Ecclesiae domaga się od nich uznania i respektowania własnego charakteru uniwersytetu. Jednym ze wskazań, które ma chronić tożsamość uczelni, jest to, aby niekatoliccy pracownicy naukowi nie stanowili większości w instytutach katolickich ${ }^{69}$.

Studenci zwykle są najliczniejszą częścią społeczności uniwersyteckiej. W ich formacji konieczny jest także wymiar etyczny. W związku z tym, należy im umożliwić katolicką formację religijną. Kształcenie w zakresie wiedzy akademickiej i zawodowej należy łączyć z formacją w duchu zasad moralnych i religijnych oraz z poznawaniem nauki społecznej Kościoła; program studiów określonego zawodu powinien obejmować także formację etyczną ${ }^{70}$. Absolwenci uniwersytetów katolickich winni wyróżniać się wiedzą, przygotowaniem do pełnienia w społeczeństwie ważnych obowiązków, ale także być świadkami wiary w świecie ${ }^{71}$.

\footnotetext{
${ }^{67}$ Tamże, art. $4 \$ 2$.

${ }^{68}$ Por. tamże, art. $4 \$ 3$.

${ }^{69}$ Por. tamże, art. $4 \$ 4$.

${ }^{70}$ Por. tamże, art. $4 \$ 5$; Szkoła i uniwersytet w życiu Kościoła i narodu, w: II Polski Synod Plenarny, nr 70.

${ }^{71}$ Por. Gravissimum educationis, nr 10.
} 


\section{Katolicki Uniwersytet Ameryki (The Catholic University of America)}

\subsection{Zarys historii}

Początki edukacji na poziomie wyższym w USA łączyły się z uczelniami prywatnymi oraz z tymi, które powstały na bazie wyznań protestanckich $^{72}$. Większy napływ katolików do tego kraju na początku XIX wieku zrodził dla nich wyzwania edukacyjne, ale najpierw na poziomie podstawowym i średnim. Dopiero w dalszej kolejności zauważono potrzebę kształcenia teologicznego, w kontekście przygotowania duchownych i katechetów ${ }^{73}$.

Katolicki Uniwersytet Ameryki został założony 13 listopada 1889 r., jako papieskie centrum badań i studiów ${ }^{74}$. Wcześniej dyskusję nad narodowym uniwersytetem katolickim podjęto podczas spotkania biskupów amerykańskich w Baltimore w 1866 r. ${ }^{75}$ Następnie 26 stycznia 1885 r. komitet biskupów, wyznaczony przez trzecie zebranie plenarne, wybrał nazwę dla nowej uczelni: Katolicki Uniwersytet Ameryki.

Jako możliwe miejsca założenia uniwersytetu rozważane były miasta: Nowy Jork i Filadelfia. Jednakże stolica USA w Dystrykcie Kolumbia, będąca centrum politycznym i symbolicznym, została uznana za najlepszą lokalizację. Ziemię pod uczelnię nabyto od instytucji „Domu Żołnierzy”, która była właścicielem terenu i budynku zbudowanego dla weteranów Wojny Secesyjnej. Papież Leon XIII 10 kwietnia 1887 r. wysłał list do kardynała Jamesa Gibbonsa,

\footnotetext{
${ }^{72}$ Por. J. BeAL, Catholic Theological Faculties in The United States, Studia Canonica 37 (2003), s. 443-446.

${ }^{73}$ Por. tamże, s. 446-453.

${ }^{74}$ Historia CUA, por. http://www.cua.edu/about-cua/history-of-CUA.cfm (data dostępu: 21.10.2014).

${ }^{75}$ Por. R. P. Malesky, The Catholic University of America, Charleston 2010, s. 9. Pierwsze dyskusje nad powstaniem uniwersytetu pojawiały się od 1819 r., por. J. T. Ellis, Catholic University of America, w: New Catholic Encyclopedia, 2 ed., t. 3, Thomson Gale 2002, s. 290.
} 
arcybiskupa Baltimore, dając wstępną formalną aprobatę dla założenia Uniwersytetu.

Kamień węgielny pod pierwszy budynek (Divinity Hall) położono 24 maja 1888 r., w obecności prezydenta USA i członków Kongresu ${ }^{76}$. Papież Leon XIII wydał 7 marca 1889 r. encyklikę Magni Nobis Gaudii, którą formalnie założył Katolicki Uniwersytet Ameryki ${ }^{77}$. Ze względu na ówczesne pierwszorzędne znaczenie Baltimore dla biskupów USA, papież wyznaczył biskupa tego miasta na wielkiego kanclerza dla nowego Uniwersytetu. W dokumencie wzmiankował też, że program wykładów z filozofii i teologii powinien być przedstawiony Stolicy Apostolskiej do zatwierdzenia. Należało także uruchomić wykłady z prawa kanonicznego. Papież zaznaczył również, że propozycje każdego $\mathrm{z}$ otwieranych wydziałów mają być w równym stopniu dostępne dla studentów duchownych i świeckich.

Biskup John J. Keane z Richmond został następnie wyznaczony na pierwszego rektora nowej instytucji ${ }^{78}$. Formalne otwarcie uczelni nastąpiło 13 listopada $1889 \mathrm{r}^{79} \mathrm{~W}$ tym samym miesiącu rozpoczęły się zajęcia uniwersyteckie, a program obejmował wykłady z filozofii, literatury angielskiej, Pisma Świętego i różnych gałęzi teologii. Wkrótce dodano wykłady z prawa kanonicznego. Dodać należy, że CUA jako pierwsza katolicka uczelnia w USA i przez szereg lat jedyna oferowała studia teologiczne na poziomie magisterskim (graduate) ${ }^{80}$

${ }^{76}$ Założenie nowej uczelni wymagało znaczących nakładów. Mary Gwendolen Caldwell była pierwszą fundatorką nowego uniwersytetu. Przekazując znaczne środki finansowe (300.000\$), zaznaczyła, że uczelnia ma być pod zarządem biskupów, nie zaś jakiegoś zakonu, z pełną propozycją studiów filozoficznych i teologicznych, por. R. P. Malesky, The Catholic University of America, s. 13.

${ }^{77}$ Por. Leo XIII, Encyclical on the Catholic University of America Magni nobis, http://www.vatican.va/holy_father/leo_xiii/encyclicals/documents/hf_l-xiii_ enc_07031889_magni-nobis_en.html (data dostępu: 23.10.2014).

${ }^{78}$ Por. R. P. Malesky, The Catholic University of America, s. 16-17.

${ }^{79}$ Por. J. T. Ellis, Catholic University of America, s. 290.

${ }^{80}$ Por. J. BeAL, Catholic Theological Faculties in The United States, s. 447. CUA oraz pięć innych odrębnych uczelni (seminariów) nadaje w USA w imieniu Stolicy Apostolskiej stopnie: bakalaureat, licencjat i doktorat, por. tamże, s. 448. 
i doktorskim ${ }^{81}$. Rozwój uczelni objął także kształcenie pedagogiczne, m.in. nauczycieli do szkół katolickich ${ }^{82}$. Wokół uniwersytetu zaczęły powstawać domy należące do różnych zakonów i zgromadzeń zakonnych, których członkowie często byli studentami nowej uczelni ${ }^{83}$. Uniwersytet pozytywnie oddziaływał na najbliższe otoczenie: Brookland, które ze względu na wielość instytucji kościelnych nazywano „Małym Rzymem" ${ }^{4}$.

Początki CUA zbiegały się z poszukiwaniami własnego stylu dla współczesnego uniwersytetu w środowisku amerykańskim. Johns Hopkins University, powstały w 1876 r., był pierwszym, w którym nie tylko nauczano. Dotąd uczelnie amerykańskie powielały angielski model (Harvard College, 1636 r.). Odmienny styl oznaczał natomiast, za wzorem pruskich uniwersytetów z XIX wieku, prowadzenie nowych badań oraz wdrożenie absolwentów do postaw badawczych. W nowej koncepcji uniwersytetów amerykańskich działalność badawcza i dydaktyczna winna być ściśle związana z praktyką życiową ${ }^{85}$. Przez odniesienie się do nowych wzorów, CUA stał się zarazem pośrednikiem, poprzez który współczesny styl uniwersytetu dotarł do amerykańskiej społeczności katolików ${ }^{86}$. Już w 1900 r. CUA był uczelnią wyższą, jedną spośród 14 innych amerykańskich, która oferowała możliwość przeprowadzenia doktoratu. W 1904 r. dodano do oferty uniwersyteckiej studia typu: undergraduate. Przykładem rozwoju oferty naukowej połączonej z badaniami, były nowoczesne laboratoria chemiczne na początku XX wieku ${ }^{87}$.

\footnotetext{
${ }^{81}$ Por. tamże, s. 454.

${ }^{82}$ Por. R. P. Malesky, The Catholic University of America, s. 53.

${ }^{83}$ Por. tamże, s. 39-41.

${ }^{84}$ Por. tamże, s. 71-86.

${ }^{85}$ Por. S. Wielgus, Historyczne koncepcje i paradygmaty uniwersytetu oraz jego model na dziś i na jutro, http://www.kul.pl/laureaci-abp-prof-dr-hab-stanislaw-wielgus,art_9891.html\#wyklad (data dostępu: 24.10.2014).

${ }^{86}$ Por. A New Type of University, http://www.cua.edu/about-cua/history-of-CUA. cfm (data dostępu: 24.10.2014).

${ }^{87}$ Por. R. P. Malesky, The Catholic University of America, s. 55.
} 
Uczelnia początkowo otwarła swe bramy dla duchownych, do których wkrótce, tj. od 1928 r., dołączyły siostry zakonne. Następnie, świeckie kobiety od 1932 r. także mogły podjąć studia. W pierwszym okresie istnienia, uczelnia otwarła się na czarnych studentów. Niestety po 1919 r. wycofano się z tej propozycji i dopiero od 1937 r. afroamerykanie ponownie mogli studiować na tej katolickiej uczelni ${ }^{88}$.

Wraz z rozwojem naukowym i powstawaniem nowych kierunków studiów, toczyło się bogate życie studenckie: społeczne i sportowe. Zwłaszcza większa liczba świeckich studentów powodowały wzmożone zainteresowanie sportem. Istniały m.in. drużyny baseballa i futbolu amerykańskiego ${ }^{89}$. Wybudowano salę sportową i pływalnię. Jeszcze w latach 20. XX wieku rozpoczęto budowę stadionu sportowego.

Różne znaczące osoby odwiedzały Uniwersytet, np. watykański sekretarz stanu kard. Eugenio Pacelli, późniejszy papież Pius XII. CUA gościł dwóch papieży. Jan Paweł II odwiedził uczelnię w 1979 r. Natomiast Benedykt XVI przybył na kampus uniwersytecki w $2008 \mathrm{r}$. W obu przypadkach, dostojni goście w swoich wypowiedziach podkreślali znaczenie katolickiego wychowania. Gdyż chodzi w nim nie tylko o zawodowe przygotowanie, czy liczbę studentów, ale także o ukształtowanie osoby, otwartej na cel ostateczny oraz na sprawiedliwość i świętośćc ${ }^{00}$.

\subsection{Aktualny kształt CUA}

Przesłania Soboru Watykańskiego II dotarły do CUA. Początkowo, decyzje personalne podejmowane przez rektora biskupa William J. McDonald's spowodowały zamieszanie w środowisku uniwersyteckim. Po interwencji wielkiego kanclerza kard. Patrick O’Boyle, nastąpiła rezygnacja dotychczasowego rektora ${ }^{91}$. Myśli soborowe przeniesiono na grunt uczelniany m.in. przez nowe ujęcie statutów

\footnotetext{
${ }^{88}$ Por. tamże, s. 87; J. T. Ellis, Catholic University of America, s. 291.

${ }^{89}$ Por. R. P. Malesky, The Catholic University of America, s. 57-59.

${ }^{90}$ Por. tamże, s. 120, 125.

${ }^{91}$ Por. J. T. ElLIs, Catholic University of America, s. 292.
} 
wydziałów kościelnych w 1968 r.92 Aktualna wersja przepisów prawnych: statutów całej uczelni pochodzi z 12 grudnia 2006 r.

Można stwierdzić, że CUA jest flagową instytucją Kościoła katolickiego w USA. Wyróżnia go m.in. sposób zarządu. Od samego początku, nadzór nad funkcjonowaniem CUA został powierzony Radzie Nadzorczej (Board of Trustees). Ścisły związek z Kościołem wyraża m.in. fakt, że do grona tej Rady wchodzą w równej liczbie: duchowni i świeccy. Rektor, nazywany w dokumentach uczelnianych prezydentem, nie musi być kapłanem ${ }^{93}$. Aktualnie Radę tworzą 48 wybierane osoby, z których 24 jest duchownymi, a z tych ostatnich przynajmniej 18 musi przynależeć do Konferencji Biskupów Stanów Zjednoczonych Ameryki ${ }^{94}$. Do grona wymienionej Rady zwykle przynależą kardynałowie będący biskupami diecezjalnymi. Wielkim kanclerzem Uniwersytetu jest każdorazowy arcybiskup Waszyngtonu ${ }^{95}$.

Bezpośredni zarząd pełni prezydent (rektor). Od 1 lipca $2010 \mathrm{r}$. jest nim prof. John Garvey. Z urzędu do Rady Nadzorczej wchodzi wielki kanclerz i aktualny prezydent CUA. Osoby wybrane do Rady służą w niej przez cztery lata i mogą być ponownie wybrane ${ }^{96}$. Pod kierunkiem prezydenta CUA, określone osoby pełnią funkcje zarządcze i administracyjne. Istotną rolę pełni senat uniwersytecki, do

\footnotetext{
${ }^{92}$ Zbiór statutów, norm i zasad, które opisują całą strukturę CUA, por. The Catholic University Of America: Faculty Handbook, Washington, D.C. 2006, http://policies. cua.edu/faculty/index.cfm (data dostępu: 29.10.2014); kolejne zmiany poszczególnych zapisów i nowelizacje są nanoszone na podaną stronę www. Statuty wydziałów kościelnych, por. tamże.

${ }^{93}$ Por. J. T. Ellis, Catholic University of America, s. 292.

${ }^{94}$ Por. Faculty Handbook Part I: The Government of the University - B. Current Governing Documents. Bylaws of the University, http://policies.cua.edu/faculty/ faculty-I/bylaws.cfm (data dostępu: 06.11.2014), section 2, nr 1; zagadnienia częstotliwości spotkań Rady, wieku członków Rady, zasad głosowania i zakresu spraw powierzonych Radzie, por. tamże, nr 1-5.

${ }^{95}$ Por. tamże, section 7; statuty CUA wskazują w tym miejscu na uprawnienia wielkiego kanclerza w odniesieniu do wydziałów kościelnych, przytaczając zapisy konstytucji Sapientia Christiana, tj. art. 12-14.

${ }^{96}$ Por. http://policies.cua.edu/faculty/faculty-I/organization/board.cfm (data dostępu: 29.10.2014).
} 
którego wybiera się proporcjonalnie pracowników z poszczególnych wydziałów, biblioteki oraz administracji i z grona studentów różnych stopni ${ }^{97}$.

Współczesny Uniwersytet łączy w sobie dobre doświadczenia katolickiej i zarazem amerykańskiej uczelni. Od 1964 r. CUA przynależy do Konsorcjum Uniwersytetów (Consortium of Univerisities) w Dystrykcie Kolumbii, co pozwala lepiej współpracować, nie tylko na poziomie instytucjonalnym, ale także pomaga studentom $\mathrm{w}$ korzystaniu z oferty edukacyjnej, badawczej i bibliotecznej. Aktualnie wymienione Konsorcjum tworzy 15 uczelni.

CUA kształci współcześnie prawie 7 tys. studentów, w tym trochę więcej niż połowę stanowią studenci kierunków na poziomie licencjackim, a pozostali na poziomie magisterskim i doktoranckim ${ }^{98}$. Studenci mają do wyboru 12 wydziałów (schools): architektury i planowania, sztuk i nauk (antropologia, sztuka, biologia, chemia, wychowanie...), biznesu i ekonomii, prawa kanonicznego, inżynierii, prawa, muzyki, pielęgniarstwa, filozofii, zawodowych studiów magisterskich dla pracujących, opieki społecznej, teologii oraz studiów zakonnych. Każda z wymienionych szkół oferuje stopnie przygotowania zawodowego oraz stopnie naukowe. Studenci wybierają spomiędzy 72 programów bakalaureackich, 103 magisterskich i 66 doktorskich.

Trzy z wymienionych wydziałów są zarazem kościelnymi. Jest to Wydział Prawa Kanonicznego (School of Canon Law), który jest jedynym tego typu wydziałem w USA $^{99}$. Wydział Teologii oraz Studiów Zakonnych (School of Theology and Religious Studies)

\footnotetext{
${ }^{97}$ Por. http://policies.cua.edu/faculty/faculty-I/organization/senate.cfm (data dostępu: 29.10.2014). Konstytucje własne Senatu CUA, por. http://policies.cua.edu/ faculty/faculty-I/governing-docs/senate.cfm (data dostępu: 30.10.2014).

${ }^{98}$ Sformułowanie „licencjackim” odnosi się w tej pracy do stopnia kształcenia: „undergraduates”, co nie jest prostym i oczywistym odpowiednikiem europejskiego poziomu studiów licencjackich.

${ }^{99}$ Historię tego Wydziału, por. J. E. LYNCH, Laying dawn the (Canon) Law at Catholic University, The Jurist 50 (1990), s. 2-57.
} 
przygotowuje studentów do pracy w różnych instytucjach kościelnych ${ }^{100}$. Do wydziałów kościelnych należy także Wydział Filozofii (School of Fhilosophy). Z CUA jest złączone ponadto seminarium duchowne (Theological College), w którym alumni z różnych diecezji amerykańskich przygotowują się do kapłaństwa. Mottem CUA jest zawołanie: „Deus Lux mea Est” (Bóg jest moim światłem). Katolicki wymiar CUA podkreślają także kolory sztandaru uniwersyteckiego: złoty i biały, tak jak na fladze Watykanu.

Studenci, tak jak to było od samego początku, mają ponadto liczne możliwości rozwoju sportowego i rekreacji ${ }^{101}$. Drużyny CUA współzawodniczą w uniwersyteckich stowarzyszeniach sportowych. Studentki mają do wyboru zajęcia sportowe w drużynach: koszykówki, hokeju na trawie, piłki nożnej, softballu, pływania, tenisa, siatkówki $\mathrm{i}$ innych. Studenci natomiast mogą uczestniczyć w sportowych rywalizacjach: baseballu, koszykówki, piłki nożnej, amerykańskiego futbolu, pływania, tenisa, lekkiej atletyki, itp.

Uniwersytet oferuje następnie bogatą propozycję rozwoju duchowego, opartego na tradycji katolickiej. Biuro duszpasterstwa akademickiego proponuje liczne formy pobożności i wzrastania duchowego: codzienną Mszę św., adoracje eucharystyczne, rekolekcje, propozycje modlitwy dla osób pochodzących z różnych wyznań i religii. Studenci biorą czynny udział w liturgii, na terenie kampusu uniwersyteckiego, jak i w narodowym sanktuarium: Bazylice Niepokalanego Poczęcia Maryi. Bazylika znajduje się na terenie kampusu uniwersyteckiego ${ }^{102}$.

\footnotetext{
${ }^{100}$ CUA wyróżnia się także ofertą programu teologii skierowaną do studentów innych wydziałów (liberal arts), w której studium teologii integruje programy studiów pierwszego stopnia. Od lat 60. w środowiskach uniwersyteckich toczyła się dyskusja nad funkcją nauczania teologii, jakie są cele nauczania tej dyscypliny wiedzy, por. J. BeAL, Catholic Theological Faculties in The United States, s. 452-453. ${ }^{101}$ Por. The Catholic University of America. 2012-2013 Annual Report, http://publicaffairs.cua.edu/res/docs/annual-report/2012-13-AnnualReport.pdf (data dostępu: 28.10.2014), s. 4-17.

${ }^{102}$ Pierwotny pomysł wybudowania kościoła maryjnego przedstawił rektor CUA: bp Thomas J. Shahan w 1910 r. Zamysł poparł papież Pius X. Kamień węgielny położono w 1920 r., a dolny kościół ukończono w 1926 r. Wielki Kryzys okresu
} 
Studenci mogą się ponadto angażować w różne formy pracy społecznej w Waszyngtonie, w innych częściach Stanów Zjednoczonych i za granicą. Wolontariusze współpracują z instytucjami charytatywnymi. Dostarczają m.in. żywność do ludzi biednych, bezdomnych, pomagają w jadłodajniach, schroniskach i ośrodkach pomocy oraz współpracują w niektórych programach misyjnych.

\subsection{Katolicki wymiar CUA}

CUA opiera się na wyżej omówionych wskazaniach i normach prawnych Kościoła, zwłaszcza Kodeksu Prawa Kanonicznego z 1983 r. i konstytucji Ex Corde Ecclesiae ${ }^{\mathbf{1 0 3}}$. Także należy przywołać konstytucję Sapientia Christiana, której normy dotyczą szczególniej wydziałów kościelnych: teologii, prawa kanonicznego i filozofii. Punktem odniesienia są ponadto normy wypracowane przez Konferencję Biskupów Stanów Zjednoczonych Ameryki. Po długim okresie dyskusji i zatwierdzeniu przez Stolicę Apostolską, normy te (Ex Corde

międzywojennego, a następnie II Wojna Światowa wstrzymały inwestycję. W trakcie Roku Maryjnego 1953-1954 biskupi amerykańscy podjęli decyzję, aby kontynuować budowę. Katolicy z USA entuzjastycznie odpowiedzieli na tę inicjatywę. 20 listopada 1959 r. nastąpiła liturgiczna konsekracja (dedykacja) świątyni. Narodowe sanktuarium zostało następnie przez Jana Pawła II podniesione do rangi bazyliki mniejszej 12 października $1990 \mathrm{r}$.

${ }^{103}$ Por. Preamble and General Statutes, http://policies.cua.edu/faculty/faculty-IV/contents/preamble.cfm (data dostępu: 02.12.2014). Refleksję CUA nad swoją tożsamością pokazuje pozycja książkowa, zapisana jako plik PDF na witrynie uczelni: The Application of Ex Corde Ecclesiae, A Ten Year Review from The Catholic University of America (dalej: Application Ex Corde Ecclesiae), http://www.cua.edu/ catholic-identity/ (data dostępu: 02.12.2014). Spojrzenie na CUA należy odnieść do historycznego kontekstu katolickich uczelni w USA (przed 1990 r.), por. P. GLEASON, The American Background of Ex Corde Ecclesiae: a Historical Perspective, w: Catholic Universities in Church and Society, s. 1-19; D. J. O’Brien, Comment, w: tamże, s. 2027; J. B. Henir, Comment, w: tamże, s. 28-31. Dyskusję na gruncie amerykańskim nad recepcją konstytucji dotyczącej uczelni katolickich, por. Ex Corde Ecclesiae. Documents; S. H. CARPenter, New Hope for Catholic Higher Education. Ex Corde Ecclesiae - a Lay Perspective, Bloomington 2006. 
Ecclesiae: An Application to the United States) zostały przyjęte na gruncie amerykańskim w $2001 \mathrm{r}^{104}$

Jako narodowy uniwersytet Kościoła katolickiego w Stanach Zjednoczonych posiada swoją specyficzną misję, zdeklarowaną w statucie. Założony i sponsorowany przez biskupów USA oraz zaaprobowany przez Stolicę Apostolską, CUA jest zobowiązany przede wszystkim do bycia wszechstronną uczelnią katolicką i amerykańską. Istotną jego cechą jest wierność nauce Jezusa Chrystusa, przekazywanej przez Kościół. Dedykuje swe działania rozwojowi dialogu między wiarą a nauką, odkrywa prawdę poprzez badania naukowe i nauczanie, pozostaje w służbie Kościoła, narodu amerykańskiego i świata ${ }^{105}$.

Idea katolickiego uniwersytetu staje się rzeczywistością wtedy, gdy cała struktura, każdy wydział, ale również pojedynczy pracownik respektuje przytoczoną wyżej misję CUA i ją wspiera. Wyżej opisane struktury zarządu, które łączą uczelnię z Kościołem katolickim, są ważne, ale formalny zapis w statutach nie zapewni automatycznie

${ }^{104}$ National Conference of Catholic Bishops United States of America, Ex Corde Ecclesiae: An Application to the United States, w: tamże, s. 388-406. Normy zostały przyjęte przez biskupów amerykańskich 17 listopada 1999 r., otrzymały recognitio Kongregacji ds. Biskupów 3 maja 2000, a promulgowane zostały z datą 1 czerwca 2000 r., natomiast zaczęły obowiązywać od 3 maja 2001 r., por. tamże, s. 407-409. Kolejna rewizja norm i ich dyskusja, por. http://www.usccb.org/beliefs-and-teachings/how-we-teach/catholic-education/higher-education/index.cfm (data dostępu: 08.12.2014).

105 "Mission Statement: As the national university of the Catholic Church in the United States, founded and sponsored by the bishops of the country with the approval of the Holy See, The Catholic University of America is committed to being a comprehensive Catholic and American institution of higher learning, faithful to the teachings of Jesus Christ as handed on by the Church. Dedicated to advancing the dialogue between faith and reason, The Catholic University of America seeks to discover and impart the truth through excellence in teaching and research, all in service to the Church, the nation and the world.", http://policies.cua.edu/ faculty/faculty-I/mission.cfm (data dostępu: 30.10.2014); Mission Statement zostało zaaprobowane 12 grudnia 2006 r., historia sformułowania misji CUA, por. tamże. Dla lepszego zrozumienia historycznego kontekstu i misji CUA, można sięgnąć do odrębnie sformułowanych celów tej uczelni: Aims and Goals of the Univeristy, por. tamże. 
katolickiej tożsamości. Każdy z pracowników i wykładowców winien reflektować, w jaki sposób może przyczynić się do tożsamości uczelni, tak jak ją definiuje konstytucja Ex Corde Ecclesiae ${ }^{106}$. Tylko takie wspólne podejmowanie odpowiedzialności przyczynia się do rozwoju uczelni, w duchu jedności z Kościołem.

Tego zadania nie mogą wypełnić jedynie same wydziały kościelne, np. w formie wykładów teologii lub filozofii, proponowanych przez te wydziały. Choć zapewne jest to znacząca część poszukiwań naukowych i nauczania myśli katolickiej. CUA odpowiada na zapisy konstytucji Ex Corde Ecclesiae przez studium teologii i nauk pokrewnych. Teologia służy społeczności wiernych w zrozumieniu i wyrażaniu prawd wiary, w pośrednictwie pomiędzy wiarą i kulturą, w komunikowaniu wiary, tak wiernym, jak i szerszej społeczności.

Misja CUA, podkreślająca łączność z Kościołem katolickim, nie wyklucza autonomii uniwersyteckiej. Uniwersytet potwierdza, że wolność badań teologicznych i innych nauk opiera się również na wskazaniach Magisterium kościelnego. Opierając się na katolickiej tradycji, na poszanowaniu prawdy, odpowiedzialności społecznej, indywidualnych prawach i również autonomii, środowisko tego Uniwersytetu podejmuje nauczanie, dyskusję i badania naukowe ${ }^{107}$. CUA respektuje prawo i odpowiedzialność poszczególnych wydziałów, profesorów i studentów w zakresie badań, publikacji naukowych, dyskusji o podstawowych założeniach i metodach, w zakresie poszczególnych nauk. Ponadto, nikt nie może być przymuszany, by negował prawdę ${ }^{108}$.

\footnotetext{
${ }^{106}$ Por. Application Ex Corde Ecclesiae, s. 5. Analogiczną myśl, w odniesieniu do wszystkich uniwersytetów, por. L. Orsy, Comment, w: Catholic Universities in Church and Society, s.149.

${ }^{107}$ Por. The University's Catholic Identity, http://policies.cua.edu/faculty/faculty-I/ catholic.cfm (data dostępu: 02.12.2014). Szerszą dyskusję nad autonomią a zarazem katolicką tożsamością katolickich uniwersytetów w USA, por. I. GRAMUnT, Autonomy and Identity of Catholic Universities in the United States, Ius Ecclesiae 4 (1992) 2, s. 463-493.

${ }^{108}$ Por. Introduction to Statement on Academic Freedom, http://policies.cua.edu/ faculty/faculty-I/governing-docs/freedom.cfm (data dostępu: 02.12.2014).
} 
Jak wyżej już to zaznaczono, trzy wydziały CUA posiadają status kościelnych: teologii, filozofii i prawa kanonicznego ${ }^{109}$. Są one także jednymi z najstarszych wydziałów uczelni. Ich głęboka łączność $\mathrm{z}$ Kościołem prowadzi do nauczania $\mathrm{z}$ jednoczesnym poszanowaniem wymagań kanonicznych. $Z$ tego powodu profesorowie, przed objęciem swoich funkcji, otrzymują misję kanoniczną od wielkiego kanclerza. Inni profesorowie (niekatolicy) także muszą otrzymać zezwolenie do nauczania od tego samego kanclerza.

Prawo amerykańskie generalnie akceptuje prawo związków religijnych do określenia, którzy ich członkowie mogą pełnić misję religijną, np. w relacji do statusu profesora teologii na uniwersytecie czy college ${ }^{110}$. W USA biskup diecezjalny miejsca, gdzie jest zlokalizowany uniwersytet, nadaje mandat dla profesorów teologii. Jest obowiązkiem profesora, $\mathrm{w}$ trakcie pierwszego roku jego zatrudnienia, postarać się o uzyskanie wspomnianego mandatu ${ }^{111}$. Jeśli zainteresowany otrzymał mandat, który nie był odwołany, przy zmianie uczelni, również gdy ta kolejna znajduje się w innej diecezji, nie musi ponownie starać się o taką autoryzację, chyba że biskup diecezjalny będzie się tego domagał ${ }^{112}$.

Pierwszym, który odpowiada za misję uniwersytetu, a jednocześnie dopełnia wymagań płynących z prawa kanonicznego jest rektor uczelni katolickiej. W tym znaczeniu można odczytać zarazem jako symboliczne wydarzenie z 25 stycznia 2011 r., kiedy nowo mianowany rektor prof. John Garvey objął swój urząd. Podczas uroczystej celebracji eucharystycznej w bazylice Niepokalanego Poczęcia Maryi, transmitowanej przez telewizję, wobec zebranych biskupów, wiernych, profesorów, studentów i pracowników CUA złożył wyznanie wiary oraz przysięgę wierności ${ }^{113}$.

\footnotetext{
${ }^{109}$ Statuty wydziałów kościelnych (historia, władze, studenci, programy studiów i stopnie naukowe), por. http://policies.cua.edu/faculty/handbook-IV.cfm (data dostępu: 03.12.2014).

${ }^{110}$ Por. J. BEAL, Catholic Theological Faculties in The United States, s. 460.

${ }^{111}$ Por. tamże.

${ }^{112}$ Por. tamże.

${ }^{113}$ Por. Application Ex Corde Ecclesiae, s. 7.
} 
Na wydziałach kościelnych wymagana jest misja kanoniczna dla wykładowców, którą nadaje biskup diecezjalny albo przynajmniej venia docendi, którą przekazuje wielki kanclerz ${ }^{114}$. Szczególny związek wydziałów kościelnych z Kościołem oznacza m.in. to, że wydział lub uczelnia powinna być zainteresowana, aby zadbać o misję kanoniczną dla zainteresowanych osób ${ }^{115}$. Warto zwrócić uwagę na formę przekazywania misji kanonicznej nowym profesorom na wydziałach kościelnych CUA. Wcześniej była ona wysyłana pocztą. Od 2008 r. w trakcie uroczystej Mszy św. rozpoczynającej rok akademicki wobec społeczności uniwersyteckiej, wielki kanclerz tuż po homilii wręcza profesorom misję ${ }^{116}$. A od $2010 \mathrm{r}$. uroczystość ta jest transmitowana w katolickiej amerykańskiej telewizji ETWN.

Kolejnym elementem, który silnie wpływa na katolickość społeczności uczelni jest duszpasterstwo akademickie. Pod kierunkiem kolejnych rektorów, senatu i Rady Nadzorczej, przeprowadzono w ostatnich dekadach rewitalizację tego duszpasterstwa. Na stałe posługują na terenie kampusu uniwersyteckiego CUA trzej kapłani zakonni (OFMConv). Ojców franciszkanów wspomaga czworo

\footnotetext{
${ }^{114}$ Por. tamże, s. 7, 15; stali wykładowcy wydziałów kościelnych otrzymują nihil obstat od wielkiego kanclerza, po uprzednim potwierdzeniu (recognito) ze Stolicy Apostolskiej, por. tamże, s. 15.

115 "Unlike the mandatum, which is the obligation of the professor to obtain, the 'canonical mission' is the obligation of the institution to obtain for the professor before his/her appointment. Professors on ecclesiastical faculties who are non Catholic receive a venia docendi, or permission to teach in the name of the Church", tamże. Dyskusję nad znaczeniem mandatum, w kontekście przygotowywania norm prawa partykularnego w USA, por. L. S. CAHILL, „Mandate” in the Context of Ex Corde Ecclesiae: a Teologian's Reflections, w: Ex Corde Ecclesiae. Documents, s. 69-87; J. A. Комоnснак, Some Theological Reflections on Canon 812, w: tamże, s. 88-103; A. Dulles, The Mandate to Teach and the Ecclesiology of Communion, w: tamże, s. 104-118. Biskupi amerykańscy, już po promulgacji norm w 2000 r., podali wskazania dotyczące udzielania mandatu na uczelniach katolickich, por. National Conference of Catholic Bishops United States of America, Guidelines Concerning the Academic Mandatum in Catholic Universities (Canon 812), w: tamże, s. 463-467. ${ }^{116}$ Por. Application Ex Corde Ecclesiae, s. 6.
} 
świeckich pracowników, zatrudnionych w pełnym wymiarze czasu w duszpasterstwie akademickim.

Jednym z ważnych wydarzeń jest uroczysta Msza św. rozpoczynająca rok akademicki. W 2008 r. podjęto decyzję, aby przenieść tę liturgię z dolnego do górnego kościoła bazyliki Niepokalanego Poczęcia Maryi. Wynikało to także z faktu, że w dolnym kościele brakowało miejsc (800-900) dla uczestniczących w uroczystości ${ }^{117}$. Pracownicy i studenci są zachęcani także do wspólnego, w ramach całej społeczności uczelnianej, świętowania i modlitwy podczas Mszy w święto patronalne Tomasza z Akwinu (styczeń). Okazją dla pracowników do wspólnej modlitwy eucharystycznej jest Msza św. poprzedzająca Boże Narodzenie. W kalendarzu CUA podkreśla się również Środę Popielcową. Dniami wolnymi od zajęć są: Wielki Czwartek, Wielki Piątek, Poniedziałek Wielkanocny, uroczystości Wniebowzięcia Maryi i Niepokalanego Poczęcia Maryi ${ }^{118}$.

Dowartościowanie duszpasterstwa akademickiego wyraża się następnie w przygotowaniu i realizacji programów ewangelizacyjnych nakierowanych na studentów i pracowników uczelni. Między innymi są to także propozycje wykładów, sympozjów, konwersatoriów i innych spotkań, w trakcie których są podejmowane dyskusje na temat wiary i tego, czym jest uniwersytet katolicki ${ }^{119}$. Kształtowanie studentów nie zamyka się tylko w przekazie wiedzy akademickiej. Chodzi również o formowanie postaw: wytrwałej pracy, osiągania dobrych stopni akademickich, dobrej zabawy, przestrzegania prawa, czynienia dobra, jak i rozwoju osobowego ${ }^{120}$.

Kształtowanie intelektualne przenika się z propozycjami natury duchowej. W kilku kaplicach na terenie kampusu codziennie jest odprawiana Msza św., w czasie najbardziej odpowiednim dla studentów i personelu. W Eucharystię czynnie włączają się studenci pełniący różne funkcje liturgiczne. Studenci są informowani o możliwościach

\footnotetext{
${ }^{117}$ Por. tamże, s. 6.

${ }^{118}$ Por. tamże, s. 12.

${ }^{119}$ Por. tamże, s. 11-15.

${ }^{120}$ Por. tamże, s. 16.
} 
korzystania z Sakramentu Pojednania. Kapłani odwiedzają chorych. Celebruje się Godzinę Świętą z błogosławieństwem. W styczniu kapłani nawiedzają i błogosławią pokoje mieszkalne studentów ${ }^{121}$. Starsi studenci włączają się aktywnie, jako animatorzy, w programy skierowane do młodszych kolegów. Wszyscy studenci mogą się włączyć w działalność różnych grup modlitewnych, charytatywnych lub misyjnych ${ }^{122}$.

Tożsamość katolickiego uniwersytetu wyraża następnie gotowość do współpracy z Kościołem powszechnym. Przykładem jest odpowiedź CUA na zaproszenie kard. Józefa Ratzingera do zorganizowania sympozjów na określone tematy ${ }^{123}$. Jeden z cykli sympozjów dotyczył znaczenia współczesnego rozumienia prawa naturalnego. Wydział Filozofii przeprowadził od 2005 r. przez szereg kolejnych lat sympozja na ten temat. Kardynał Józef Ratzinger poprosił również Uniwersytet o zorganizowanie sympozjów na temat moralnych pryncypiów, co nastąpiło w 2008 r.

Gotowość do wyrażenia jedności z Kościołem i służby dla niego, społeczność akademicka przejawiła ponadto w kontekście przygotowania wizyt papieskich. Pierwsza z nich nastąpiła w 1979 r., kiedy Jan Paweł II spotkał się ze społecznością uniwersytecką. Druga z nich wiązała się z papieżem Benedyktem XVI, który przebywał na terenie kampusu CUA 17 kwietnia 2008 r. W przygotowanie wizyty, zaprojektowanie dekoracji i wystroju, np. ołtarza, czynnie włączyli się studenci i Wydział Architektury.

Na koniec można także zasygnalizować zagadnienia ekonomiczne. Z jednej strony związek CUA z Konferencją Biskupów Stanów Zjednoczonych Ameryki wyraża coroczna kolekta pieniędzy,

\footnotetext{
${ }^{121} \mathrm{~W}$ polskiej tradycji jest to odpowiednikiem wizyty duszpasterskiej, tzw. kolędy. ${ }^{122}$ Więcej na temat różnych form duszpasterstwa akademickiego, w którym studenci są nie tylko odbiorcami, ale również aktywnymi świadkami wiary, por. Application Ex Corde Ecclesiae, s. 16-21. Na dalszych stronach tej pozycji przedstawiono poszczególne wydziały i struktury CUA, w relacji do praktycznych form budowania katolickiej tożsamości uczelni, por. tamże, s. 22-32.

${ }^{123}$ Por. tamże, s. 8-9.
} 
przeprowadzana w całym kraju, na potrzeby tej uczelni ${ }^{124}$. Z drugiej strony, Uniwersytet wnosi swój wkład w dzieła kościelne ${ }^{125}$. Zabiegając o fundowanie stypendiów, programy sponsorskie i inne formy wsparcia finansowego, CUA wnosi swój wkład w potrzeby ogólno kościelne. Utrzymuje trzy wydziały kościelne. Dofinansowuje duszpasterstwo akademickie, m.in. poprzez zatrudnienie duszpasterzy i świeckich pracowników. Funduje stypendia dla katolickich nauczycieli i część stypendiów dla seminarzystów studiujących na Uniwersytecie oraz utrzymuje budynek dla nich przeznaczony.

\section{Zakończenie}

Potrzeba rozbudowania form edukacji na wyższym poziomie spowodowała powstanie wielu uniwersytetów i innych uczelni katolickich w Stanach Zjednoczonych Ameryki. Jednocześnie z ich powstawaniem, pod kierunkiem biskupów diecezjalnych i instytutów zakonnych, rodziła się myśl zainicjowania uczelni reprezentacyjnej i zależnej od wszystkich biskupów USA. Pod koniec XIX wieku powstał w Waszyngtonie Katolicki Uniwersytet Ameryki, który przyjął rolę katolickiej flagowej uczelni w USA. Trudne początki nie zraziły jego założycieli. Uniwersytet zaaprobowany przez papieża Leona XIII zaistniał w 1889 r. Jego początkowy i dalszy rozwój przeplatał się z historią USA oraz katolików amerykańskich.

CUA realizuje zadania typowe dla uczelni wyższej: kształci studentów, prowadzi badania naukowe, rozwija kadrę nauczycielską i współpracuje z innymi ośrodkami naukowymi. Równocześnie posiada wyraźnie katolicki charakter. Wyraża go m.in. więź strukturalna

\footnotetext{
${ }^{124}$ Por. Sponsorship, http://www.cua.edu/catholic-identity/catholic-intellectual-tradition.cfm (data dostępu: 24.10.2014). Po raz pierwszy, za papieską aprobatą, przeprowadzono kolektę na potrzeby uczelni w całym kraju w 1903 r., por. J. T. ELLIs, Catholic University of America, s. 291. Raport finansowy CUA stanowi część dorocznego sprawozdania publikowanego na stronie uniwersyteckiej, por. The Catholic University of America. 2012-2013 Annual Report, http://publicaffairs.cua. edu/res/docs/annual-report/2012-13-AnnualReport.pdf (data dostępu: 28.10.2014), s. 37-40.

${ }^{125}$ Por. Application Ex Corde Ecclesiae, s. 32.
} 
z Kościołem katolickim: na 48 członków Rady Nadzorczej, 24 jest duchownymi, a z tych ostatnich 18 należy do Konferencji Episkopatu Biskupów Amerykańskich.

Trzy wydziały posiadają status kościelnych: teologia, prawo kanoniczne i filozofia. Są one ukierunkowane na studium Objawienia chrześcijańskiego. Wydziały kościelne stanowią doskonały pomost dla dialogu między wiarą a rozumem. Poprzez swoją własną przestrzeń badawczą dopełniają poszukiwania innych nauk, z którymi razem stanowią universitas. Profesorowie tych wydziałów otrzymują misję kanoniczną. Przekazanie misji kanonicznej dokonuje się w ostatnich latach w sposób publiczny, podczas uroczystości wspólnej dla całej społeczności uniwersyteckiej.

Katolicki wymiar uniwersytetu wyraża następnie jego misja. Wskazuje ona na wierność nauce Jezusa Chrystusa, którą przekazuje Kościół. Uczelnia dedykuje swe działania rozwojowi dialogu między wiarą a nauką, odkrywa prawdę poprzez badania naukowe i nauczanie, pozostaje w służbie Kościoła, narodu amerykańskiego i świata.

Formalne powiązania z Kościołem katolickim oraz misję uczelni dopełnia kolejny element. W zapisach statutowych oraz w praktyce kładzie się nacisk na zaangażowanie wszystkich członków społeczności uniwersyteckiej w kształtowanie katolickiej tożsamości CUA. Zapisy prawne, jak również etos uczelniany, prowadzą następnie do kształtowania postaw chrześcijańskich. A ponadto, w poszukiwaniach naukowych CUA odwołuje się do inspiracji chrześcijańskich. Następnie należy zauważyć dyspozycyjność Uniwersytetu na oczekiwania płynące od hierarchii kościelnej. Wyrazem tego było np. zorganizowanie kilku cykli sympozjów, na tematy zaproponowane przez kard. Józefa Ratzingera.

Bardzo wyraźnie rysuje się wielość propozycji w ramach duszpasterstwa akademickiego. Oprócz zatrudnienia na pełnym etacie: kilku kapłanów i osób świeckich, zauważa się różnorodność ofert tego duszpasterstwa. Są one uzgadniane tak, aby np. propozycje modlitwy i Eucharystii dostosować do czasu wolnego studentów i pracowników. Podejmowane działania są wcześniej zaprogramowane, a następnie weryfikowane i ewaluowane. 
Wysiłek duszpasterzy, świeckich pracowników i wielu animatorów (spośród samych studentów) włożony w organizację duszpasterstwa akademickiego łączy się także z wymiarem finansowym. Uniwersytet ten w pełni finansuje duszpasterstwo akademickie. A ponadto należy dodać, że CUA utrzymuje trzy wydziały kościelne, funduje stypendia dla katolickich nauczycieli i części seminarzystów studiujących na Uniwersytecie. Uczelnia ta będąc prywatną musi aktywnie poszukiwać środków finansowych i sponsorów, aby zabezpieczyć wszystkie realizowane zadania.

Przykład CUA wydaje się być inspiracją dla tych polskich uczelni, które są związane z Kościołem katolickim. Szczególniej nasuwają się dwie myśli. Po pierwsze, nie tylko należy przestrzegać wymogów dotyczących nadania misji kanonicznej lub mandatu (kan. 812). Przekazanie tych specyficznych na gruncie kanonicznym autoryzacji dla profesorów można by dokonywać w sposób publiczny. Nie chodzi tylko o samo kanoniczne umocowanie profesora na wydziale kościelnym lub innym. Wykorzystanie uroczystości uczelnianych do wręczenia stosownych dokumentów wskazuje na istotny związek zainteresowanych wykładowców z Kościołem katolickim, jak również na katolicki lub kościelny wymiar samych wydziałów.

Po drugie, współczesnym wyzwaniem w Polsce, jak i w Europie, jest duszpasterstwo akademickie, tak studentów, jak i całego środowiska universitas. Aby oddziaływanie duszpasterskie było owocne, nie można poprzestać na wydzieleniu kościołów akademickich i liturgii tamże sprawowanej. Raczej chodzi o to, by budować zespoły osób: duchownych i świeckich podejmujących to duszpasterstwo. Następnie należałoby poszukiwać studentów, niejako wychodzić do nich i przyprowadzać do Kościoła: communio. Duszpasterstwo akademickie wymaga także pracy zaplanowanej, więc zaprojektowanej, którą należy następnie ewaluować. 


\section{The Catholic University of America in the light of norms of canon law}

Universities take a significant part in education of students as well as in scientific researches. Catholic Church also actively participates in the world of science i.e. by running catholic universities. Above study concerns The Catholic University of America, which was founded at the end of 20th century (in 1889). It functioned as a flagship catholic university in the USA. By introducing exactly that university one can understand how the instructions from The Church's Magisterium and how canon norms apply in practice. The first part of the article analyses norms of canon law concerned with catholic universities, including the term university and its practical applications. Then, it discusses issues concerning the academic community. In the second part of the study it outlines the history of The University in Washington, its present form, and catholic dimension.

The university accomplishes objectives typical to university: it educates students, conducts scientific researches, develops skills of teaching staff and cooperates with different research centers. At the same time university evidently preserves catholic nature, which is visible in structural bond between Catholic Church and the university (24 members of Supervisory Board out of 48 seems to be clerics, and from them there are 18 people who belong to United States Conference of Catholic Bishops). The university has three church faculties, which state an excellent bridge between the faith and the mind. Professors receive canonic missions.

The catholic dimension of the university is represented by its mission and statute regulations. The mission concerns faithfulness to a Jesus Christ. The university dedicates its activities to develop a bond between the faith and the science. It also reveals truth through scientific researches, and teaching. It remains in service to the Church, American nation, and the whole world. The university places emphasis on involvement of all members of academic community in developing catholic identity of CUA. The university also responds to the expectations from church hierarchy, which regard prospecting and scientific research. The multitude of proposals from university chaplaincy, as well as the university's commitment in that matter is clearly outlined.

The example of described university might be an inspiration to those Polish universities, which are bond with The Catholic Church. It particularly regards a manner of handing canonic mission or mandate down (can. 812). 
The act of giving mission can be public, during ceremony for the whole of academic community. This kind of method points out a significant relation between the academic teachers, and The Catholic Church. Also it shows the clerical dimension of those faculties. Moreover, the example of university chaplaincy in that particular university, that is: multitude of ideas and structural solutions, could be a reason for Polish universities to search for new ideas in that scope.

SŁOWA KLUCzOWE: uniwersytet, uniwersytet katolicki, Katolicki Uniwersytet Ameryki w Waszyngtonie, prawo kanoniczne

KEYwORDs: the university, Catholic university, the Catholic University of America in Washington, the canon law

\section{Nota o Autorze:}

Ks. DR hab. Arkadiusz Domaszk SDB, Prof. UKSW - profesor nadzwyczajny na w Katedrze Prawa o Posłudze Nauczania Wydziału Prawa Kanonicznego UKSW w Warszawie, p.o. kierownika Zakładu Prawa o Dobrach Doczesnych Kościoła w Katedrze Kanonicznego Prawa Administracyjnego i Prawa o Dobrach Doczesnych Kościoła. 